\title{
Biyoetik dersinde kullanılan filmlerin etik farkındalık geliştirme üzerine etkisi: Dallas Buyers Club filminin analizi üzerinden bir değerlendirme ${ }^{*}$
}

\section{The effect of films used in bioethics course on ethical awareness development: An evaluation based on} the analysis of the movie Dallas Buyers Club

\author{
Şenay Güli', Serap Şahinoğluii \\ i Dr., Hacettepe Üniversitesi Hemşirelik Fakültesi Hemşirelik Esasları AD., https://orcid.org/0000-0002-8808-5760 \\ ii Prof. Dr., Ankara Üniversitesi Tıp Fakültesi Tıp Tarihi ve Etik AD.,https://orcid.org/0000-0003-4462-2402
}

öz

\begin{abstract}
Amaç: Bu çalışma Disiplinlerarası Kök Hücre ve Rejeneratif Tıp yükseklisans programında verilen Kök Hücre Politikaları ve Biyoetik dersinde film izlemenin öğrencilerde etik farkındalık geliştirme üzerine etkisini belirlemek amacıyla yapılmıştır.

Yöntem: Bu çalışma retrospektif bir araştırmadır. 2018-2019 ve 2019-2020 Öğretim yılı bahar dönemlerinde, Kök Hücre Politikaları ve Biyoetik dersi alan 17 öğrencinin ödev metinleri çalışmaya dahil edilmiştir. Öğrencilere ilk hafta Dallas Buyers Club filmini izlemeleri, etik açıdan filmi değerlendirip yazılı olarak dersin sorumlu öğretim üyesine iletmeleri istenmiştir. Dersin son haftasında öğrencilerle ders boyunca aldıkları bilgiler ışığında Dallas Buyers Club filmini etik bir zeminde değerlendirmeleri istenmiş ve öğrencilerin görüşleri yazılı metin haline getirilmiştir. Öğrencilerin ders öncesi ve sonrasında etik sorunlarla ilgili filmden yola çıkarak yaptıkları tartışma metinlerinden elde edilen veriler, araştırmacılar tarafından analiz edilmiş ve raporlanmıştır.

Bulgular: Öğrencilerin, dersin ilk haftasındaki değerlendirmelerinde filme konu olan etik sorunların çoğunu, son hafta yaptıkları tartışma oturumunda ise tamamını fark ettikleri, çözüm için önerilerde bulundukları belirlenmiştir. Öğrenciler biyoetik dersinde filmler üzerinden yapılan tartışmaların etik sorunları daha iyi farketmelerine katkı sağladığını, ilgili filmlerin etik eğitiminde kullanılmasının yararlı ve etkili olduğunu belirtmişlerdir.

Sonuç: Etik eğitiminde kullanılan film analizinin öğrencilerin etik sorunlarla ilgili farkındalıkları üzerinde olumlu etkisi olduğu görülmüştür. Sağıık bilimlerinin lisansüstü programlarında verilen etik eğitimi ile ilgili farklı öğretim yöntemlerinin karşılaştırarak daha fazla araştırma yapılması gerekmektedir.
\end{abstract}

Anahtar kelimeler: Biyoetik, etik eğitimi, etik sorunlar, film kullanımı, araştırma etiği

\section{ABSTRACT}

Aim: This study was conducted to determine the effect Stem Cell Policies and Bioethics course given in Interdisciplinary Stem Cell and Regenerative Medicine Master Program on ethical awareness development through the movie.

Methods: This study is a retrospective research. In the spring semesters of 2018-2019- and 2019-2020 academic years, within scope of Stem Cell Policies and Bioethics course, students were asked to watch the Dallas Buyers Club movie in the first week of the course, evaluate it ethical problems and send it to the lecturer in writing. In the last week of the course, the students were asked to re-evaluate the movie in terms of ethical problems in the light of the information they received during the course and the opinions of the students were made into written text. The data obtained from the discussion texts made by students about ethical problems before and after the course were analyzed and reported by the researchers.

Results: In the study, it was determined that while the students included most of the evaluations of the ethical problems that were the subject of the film in the first week of the course, they realized all of them in their discussion session last week and made suggestions for solution. The students stated that discussions made over films in the bioethics lesson contributed to their awareness of ethical problems better, and that it was useful and effective to be used in ethics education.

Conclusion: It was observed that the film analyses used in ethics education had a positive effect on students' awareness of ethical issues. More research needs to be done by comparing different teaching methods related to ethics education provided in postgraduate programs of the health sciences.

Key words: Bioethics, ethics education, ethical issues, using film, research ethics

*Lokman Hekim Dergisi, 2020; 10 (3): 502-509

DOI: 10.31020/mutftd.776047

e-ISSN: 1309-8004, ISSN 1309-761X

Geliş Tarihi - Received: 30 Temmuz 2020; Kabul Tarihi - Accepted: 13 Eylül 2020

Iletişim - Correspondence Author: Şenay Gül <senaygundogmus@gmail.com>

Etik onay: Çukurova Üniversitesi Tıp Fakültesi Girişimsel Olmayan Klinik Araştırmalar Etik Kurulu (50243401/2020-18) 


\section{Giriş}

Eğitim, çevre düzenlemesi yoluyla bireyde istendik davranış değişikliği oluşturma süreci olarak tanımlanmaktadır. ${ }^{1}$ Başka bir tanımda ise kişiliğin gelişmesine yardım eden ve onu temel alan, bireyi yetişkin yaşamına hazırlayan, gerekli bilgi, beceri, tutum ve davranış kazanmasına yarayan bir süreç olarak ele alınmıştır. ${ }^{2}$ Mesleki profesyonelliğin en önemli ölçütlerinden birisi nitelikli bir eğitim almak ve mesleki etik ilkeleri benimsemektir. Profesyonellik aynı zamanda etik bilinç ve duyarlılık gerektirmektedir. Etik eğitiminin amacı etik farkındalık, duyarlılık ve yeterlik geliştirmek, etik sorunların çözümünde bilgi ve beceri geliştirmektir. $^{3}$

Teknolojik ilerlemenin çok hızlı geliştiği günümüzde etik eğitiminin gerekliliği daha da önem kazanmıştır. Çünkü teknolojinin gelişimi ile her geçen gün tartışıması gereken yeni etik sorunlar ortaya çıkmakta, sağlık profesyonelleri de bu gelişmelerle birlikte sağıı bakım ortamlarında etik ikilemlerle çok sık karşı karşıya kalmaktadırlar. ${ }^{4}$

Sağlık profesyonellerinin etik karar verebilmesi, etik duyarlılık geliştirebilmesi, bilimsel ve teknoloji temelli etik konuları tanımlayabilmesi, etik sorunların farkına varabilmesi ancak ahlaki değerleri tanıması, değerlendirmesi, ilerleyen süreçlerde bunun üzerine empati yapabilmesi ile mümkün olmaktadır. Bireyin kişisel ve toplumsal olarak edindiği ahlaki değerler, etik eğitimi ile biçimlenmektedir. Bu nedenle etik eğitimi, sağlık profesyonellerinin değer eğitiminde önemli ve gereklidir.

Etik eğitiminde tercih edilecek olan öğretim yöntemlerinin, öğrencilerin ahlâki gelişimini destekleyecek ve etik sorunlara yaklaşımı konusunda donanımlı yetişmelerini sağlayacak nitelikte olması gerekmektedir. ${ }^{5}$ Etik eğitiminde derslerde filmlere yer vermek yenilikçi bir yöntem olarak değerlendirilmektedir. Filmler, birden fazla duyu organına hitap etmesi, hatırlamayı kolaylaştırması, bilgilerin gerçek yaşama dönüştürülmesi ve duyguların tanımlanmasına yardımcı olması gibi etkileriyle öğrenimi kolaylaştırmaktadır. ${ }^{6-8}$ Alanyazında ayrıca sağlık profesyonellerinin etik eğitiminde filmlerin kullanılması, öğrenci merkezli öğrenmeyi kolaylaştırdığı, grup öğrenimine katkı sağladığı, klasik eğitimden farklı olarak filmlerde sunulan öykülerin kritik düşünme ve problem çözme potansiyeli üzerinde daha etkili olduğu belirtilmektedir. ${ }^{9,10}$

Alanyazında etik eğitiminde kullanılan film izletme yönteminin farkındalık geliştirme üzerine etkisi ile ilgili çalışmalar sınırlı olduğu gibi ${ }^{10-13}$ ülkemizde film izlemenin etik eğitiminde kullanımına ilişkin araştırmalara da rastlanmamıştır.

Bu çalışma Disiplinlerarası Kök Hücre ve Rejeneratif Tıp yükseklisans programında verilen Kök Hücre Politikaları ve Biyoetik dersinde kullanılan film izleme yönteminin, öğrencilerin etik farkındalık geliştirme üzerindeki etkisinin, Dallas Buyers Club (Sınırsızlar Kulübü) filmi üzerinden belirlenmesi amacıyla yapılmıştır. Elde edilen bulguların, sağlık profesyonellerine verilen biyoetik dersi ve değer eğitiminin geliştirilmesinde yol gösterici olacağı düşünülmektedir.

\section{Yöntem}

Bu çalışma retrospektif olarak tasarlanmıştır. Veriler, 2018-2019 ve 2019-2020 öğretim yılı bahar döneminde verilen Kök Hücre Politikaları ve Biyoetik dersi kapsamında öğrencilerden istenen ve sorumlu öğretim üyesinin kişisel arşivinde bulunan öğrenci ödev metinleri kullanılarak elde edilmiştir.

Kök Hücre Politikaları ve Biyoetik dersi kapsamında; etik ile ilgili temel kavramlar, tanımlar, etik ilkeler, etik yaklaşımlar, etik çözümleme, insan hakları, etik kurullar, araştırma ve yayın etiği, sağlık alanında cinsiyetçilik konuları ele alınmıştır. Ders kapsamında öğrencilere Miss Evers' Boy, The Lady in the Van, Welcome ve Dallas Buyers Club filmleri izletilmiştir. Bu çalışmada filmin konusunda geçen etik sorun yelpazesinin oldukça geniş olması, AiDS gibi tedavi seçeneği arayışında olduğumuz bir hastalığı temel alması ve araştırma etiği bağlamında konuyu irdelemesi nedeniyle Dallas Buyers Club filminin seçimine karar verilmiştir.

Kök Hücre Politikaları ve Biyoetik dersini 2018-2019 öğretim yılında 9, 2019-2020 öğretim yılında 8 olmak üzere toplam 17 öğrenci almıştır. Kök Hücre Politikaları ve Biyoetik dersini 2018-2019 veya 2019-2020 öğretim yılında almak, dersten geçmiş olmak, derste öğretim elemanının verdiği Dallas Buyers Club filminin etik açıdan incelenmesi ödevini yapmak araştırmaya dahil edilme kriterleridir. Araştırmada ödevlerin kullanılmasına izin vermemek, belirtilen ödevlerin eksik olması, dersi geçememek ise araştırmanın dışlanma 
kriterleri olarak belirlenmiştir. Araştırma kritelerine uyan 17 öğrencinin ödev metinleri çalışmaya dahil edilmiştir.

2018-2019 ve 2019-2020 öğretim yılı bahar döneminde, ilgili ders kapsamında, öğrencilere ilk hafta Dallas Buyers Club filmini izlemeleri, filmi özetlemeleri, filmde geçen etik sorunları belirlemeleri ve yazılı olarak dersin sorumlu öğretim üyesine vermeleri istenmiştir. Dersin son haftasında tekrar bir oturum yapılarak filmde geçen etik sorunlar ve çözüm önerileri hakkında öğrencilerle tartışılıp, not edilen öğrenci ifadeleri yazılı metin haline getirilmiştir. Ayrıca bu oturumda, öğrencilerin film hakkındaki genel izlenimleri, düşünceleri ve filmin etik eğitiminde kullanımının yararlı olup olmadığını belirtmeleri de istenmiştir.

Bu çalışma kapsamında öğrencilerin dersin başında ve sonunda verdikleri görüşleri karşılaştırılarak, film izleme yöntemi kullanılarak verilen dersin, etik farkındalık üzerindeki etkisi belirlenmeye çalışılış̧ır.

Öğrencilerin tamamının dersin ilk ve son haftasında yaptıkları etik sorunlara yönelik değerlendirmeleri, dersin sorumlu öğretim üyesi (SŞ) ve diğer araştırmacı tarafından (ŞG) eş zamanlı olarak analiz edilmiş ve raporlanmıştır. Öğrencilerin söylemlerine alıntı olarak yer verilmiştir. Alıntının hangi öğrenciye ait olduğunu göstermek için Ö1, Ö2 şeklinde kodlama kullanılmıştır.

\section{Araştırma sürecinin etik boyutu}

Çalışmanın yapılabilmesi için Çukurova Üniversitesi Tıp Fakültesi Girişimsel Olmayan Klinik Araştırmalar Etik Kurulu'ndan (50243401/2020-18), Ankara Üniversitesi Kök Hücre Enstitüsü'nden yazılı izin alınmıştır. Ödev metinlerini kullanabilmek üzere öğrencilerden sözel onam alınmış, ödevlerinin değerlendirilmesine izin veren öğrencilerin tartışma metinleri araştırmaya dahil edilmiştir. Öğrencilerin kişisel bilgilerine çalışmada yer verilmemiştir.

\section{Dallas Buyers Club Filmi}

2013 yılında Amerika'da çekilen film, 1992 yılında gazeteci Bill Minutaglio'nun Dallas Morning News Gazetesi'nde yer alan haberinden yola çıkarak Ron Woodroof'un gerçek yaşam hikâyesi üzerine kurgulanmıştır. Film ülkemizde 2014 yılında "Sınırsızlar Kulübü" adı ile gösterilmiştir. Filmin başkarakteri olan Ron, rodeo, kumar, alkol alışkanlıkları olan ve kadınları sadece birer cinsel obje olarak gören, toplumsal cinsiyet rolü ataerkil bakış açısının etkisi altında biçimlenmiş Teksas'lı bir elektrik işçisidir. Filmde Ron'un HIV pozitif olduğunu, devamında da AIDS hastalığına yakalandığını öğrenmesi ve hastalığına çare aramasıyla geçen süreç anlatılmaktadır.

Ron, önce hastalığını kabullenmez, hekim ve sağlık çalışanlarına hakaret ederek hastaneyi terk eder. Hastalığı hakkında araştırma yaptığı sırada bir ilaç firmasının düzenlediği, AZT adlı yeni geliştirilmekte olan bir ilacın tanıtımına katıır. Toplantı sonrası hastanede ilaçla ilgili deneysel çalışmaya katılmak ister. Çalışma, AZT'nin bir grup hastaya verildiği, bir başka grup hastaya ise plesebo uygulanarak sonuçların değerlendirildiği bir araştırmadır. Ron bu çalışmaya kabul edilmez ve gizli olarak hastane çalışanlarına para vererek bir süre bu ilacı kullanır. Illacı temin olanakları bozulunca alternatif yollar aramaya başlar.

Bu sırada hastalanır ve hastaneye yeniden kaldırılır. Burada eşcinsel Rayon ile tanışır. Ron homofobik olduğu halde bir süre sonra Rayon ile yolları kesişir ve hastalıkları süresince birlikte hareket ederek hem dost hem de iş ortaklığı yaparlar. AIDS için tedavi arayışları sırasında Meksika'daki yeni çalışmaları öğrenip Dr. Vess'den bu ilaçları temin ederler. Bunlar, Food and Drug Administration (FDA) tarafından onaylanmamış ilaçlardır.

Araştırmaları sırasında hastanede deneysel amaçla kullanılan AZT'nin aslında hastalığı tedavi etmediği, hatta hastalar için zararlı olduğunu öğrenirler. Dr. Vess'ten aldıkları yeni ilaç Ron'a çok iyi gelir ve kendini toparlamaya başlar. i̇lacın işe yaradığını gören Ron, bunu ticarete dönüştürür ve kaçak yollarla ilacı ülkeye getirir. Dallas Buyers Club (Sınırsızlar Klübü) adını verdikleri üyelikle ilacı satmaya başlarlar. Bu ortaklık aynı zamanda Ron'un homoseksüellere karşı olan katı tutumundan uzaklaşmasına ve cinsiyetçi değer sisteminde dönüşüme neden olur. Ancak bir süre sonra hastalığı ilerleyen Rayon yaşamını kaybeder. Kurmuş oldukları kulüp birçok kez FDA tarafından basııı. Baskınlar karşısında FDA'ya dava açan Ron, davayı kaybeder ancak mahkeme yaşaması için gerekli olan Peptit $T$ adlı ilacı kullanmasına izin verir. Yaşamda kalmak için verdiği 
mücadele sayesinde HIV pozitif tanısı konulduğu sırada bir aylık ömür biçilen Ron Woodroof, 12 yıl sonra yaşamını kaybeder.

Ayrımcılık, etiketleme, kötü haber verme, sağlık profesyonelleri ve toplum bireyleri tarafından hastaların ötekileştirilmesi, hayvan hakları ihlali, ırkçılık, insanlar üzerindeki ilaç araştırması ile ilgili etik sorunlar, ilaç endüstrisi-hekim ilişkilerinden doğan etik sorunlar, modern tıbba inanan bir hekimin sistemden rahatsızlığı ve yetersiz tedaviler karşısında ikilemde kalması, ilacın yan etkilerinin göz ardı edilmesi, plasebo uygulamasının açıkça hastalara anlatılmaması, hastalık ile ilgili yeterli bilgilendirmenin yapılmaması, aydınlatılmış onam alınmaması, sağlık hizmetlerinin sunumunda adaletsizlik, hasta özerkliğinin göz ardı edilmesi ve mahremiyet filmde göze çarpan başlıca etik sorunlar arasındadır. Bunlar temelde biyoetik, biyopolitika ve biyoiktidar açısından önemli sorunlardır. Film bu başlıkları ortaya koyarak etik sorunun aslında ne kadar büyük olduğunu da göstermektedir.

\section{Bulgular}

Çalışmada öğrencilerin filme konu olan etik sorunların çoğuna dersin ilk haftasındaki değerlendirmelerinde yer verdikleri, son hafta yaptıkları tartışma oturumunda tamamını fark ettikleri, etik sorunların çözümü için önerilerde bulundukları saptanmıştır.

Tablo 1. Öğrencilerin Kök Hücre Politikaları ve Biyoetik dersinin ilk haftasında ve son haftasında Dallas Buyers Club filminde belirledikleri temel etik sorunlar

\begin{tabular}{|c|c|}
\hline $\begin{array}{l}\text { Öğrencilerin dersin ilk haftasında belirledikleri etik } \\
\text { sorunlar }\end{array}$ & $\begin{array}{l}\text { in son haftasında ilk hafta belirlenen } \\
\text { ak belirledikleri etik sorunlar }\end{array}$ \\
\hline $\begin{array}{ll}\text { - } & \text { Aydınlatılmış onam alınmaması } \\
\text { - } & \text { Cinsiyete dayalı ayrımcılık } \\
\text { - } & \text { Sağlık hizmetlerinin sunumunda adaletsizlik } \\
\text { - } & \text { Hasta özerkliğine saygı gösterilmemesi } \\
\text { - } & \text { Ayrımcılık } \\
\text { - } & \text { Etiketleme } \\
\text { - } & \text { Modern tıbba inanan bir hekimin sistemden } \\
& \text { rahatsızlığı ve yetersiz tedaviler karşısında } \\
& \text { ikilemde kalması } \\
\text { - } & \text { Bireyin toplum tarafından ötekileştirilmesi }\end{array}$ & $\begin{array}{l}\text { - Hayvan hakları ihlali } \\
\text { - } \quad \text { ilaç endüstrisi-hekim ilişkilerinden doğan etik } \\
\text { sorunlar } \\
\text { - } \text { Mahremiyet } \\
\text { - } \quad \text { Bireyin sağlık çalışanları tarafından } \\
\text { ötekileştirilmesi } \\
\text { - } \quad \text { ilaçaraştırmaları ile ilgili etik sorunlar } \\
\text { - Plasebo uygulamasının açıkça hastalara } \\
\text { anlatılmaması }\end{array}$ \\
\hline
\end{tabular}

Öğrencilerin pekçoğu dersin ilk haftasında filmde geçen etik sorunlardan birini aydınlatılmış onam alınmaması olarak belirlemiştir:

"Hekimin hasta ve insan haklarına aykırı eylemde bulunarak hastanın rızası olmadan, ona HIV testi yapması etik bir sorundur." (Ö4)

"Hekimin hastayı hastalığı ile ilgili tam olarak bilgilendirmemesi etik bir sorundur." (Ö1)

"Başvurduğu sağlık kurumu tarafından Ron'a AIDS hastalığı ve bulaş yolları ile ilgili eğitim verilmediğinden, kendisinin ve çevresinin sağlığı için riskli olan davranışları yapmayı sürdürdüğü görülmektedir." (Ö3)

Filmden yola çıkarak belirlenen bir başka etik sorun, sağlık hizmetinin sunumunda adaletsizlik olarak belirtilmiştir. Bir öğrencinin ifadesi şu şekildedir:

"Temel etik sorunlardan bir tanesi adalettir. Bir tedavi var ve herkes ulaşamıyor. Sınırlı sayıda ve sadece parası olan tedaviye ulaşabiliyor, parası olmayan ölmeye mahkum ediliyor." (Ö1)

Öğrenciler film üzerinden yapılan her iki tartışma oturumunda da ayrımcılık, etiketlenme, ötekileştirme etik sorunlarının göze çarptığını belirtmişlerdir.

"HIV pozitif olmanın getirdiği korku, utanç ve çaresizlik duygularıyla, bilgisizliğin doğurduğu toplumsal 'dışlanma' ve 'etiketlenme' faktörlerinin de devreye girmesiyle Ron hepimizin sahip olduğu 'hayatta kalma' içgüdüsü ile hareket ediyor." (Ö3) 
"Aşırı derecede homofobik olan Ron, AIDS olduğunu öğrenince etrafında kimse kalmıyor, dışlanıyor ve homoseksüeller gibi 'ötekileştiriliyor'." (Ö8)

"Hastalığın homoseksüel bireyler arasında yaygın olması, devlet ve ilaç şirketleri için bu hasta grubunun bir nevi denenebilir olarak yansıtılıyor ve ayrımcllık yapılıyor." (Ö13)

Hasta özerkliğine saygı gösterilmemesi, filmi yorumlayan öğrenciler tarafından belirlenen başka bir etik sorundur:

"Hastaların tedaviyi reddetme, değiștirme hakkı varken, hekimler Ron'un bu istediğini göz ardı etmişlerdir." (Ö16)

Dersin ilk haftasında öğrencilerden sadece bir tanesi hekimin sistemden rahatsızlığı ve yetersiz tedaviler karşısında ikilemde kalmasını filmde geçen etik sorunlardan biri olarak belirlemiştir. Öğrencinin ifadesi aşağıda yer almaktadır:

"Dr. Eve ilaç şirketinin güvenilmez olduğunu fark eder ve hastaların yaşama hakkı için içten içe mücadele etmeye yönelip tedavi için bazı araştırmalar yapmaya başlar." (Ö13)

Dersin son haftasında film üzerinden yapılan tartışmada öğrencilerin çoğu ilaç endüstrisi-hekim ilişkilerinden doğan etik sorunları fark etmiştir. Öğrencilerin bu konu ile ilgili ifadeleri aşağıda yer almaktadır.

"Devletle ilaç firması arasındaki anlaşma nedeniyle eleştirilere rağmen AZT tedavisine devam edilmektedir. Tedaviyi başarılı gösteren yayınlara yer verilmekte, ölen hastalar gizlenmektedir." (Ö1)

"ilaç firmalarının maddi kazancı için insan hayatı tehlikeye atılıyor. ilacın yan etkisinden dolayı birçok insan hayatını kaybediyor ve hastalara gerçekler söylenmiyor." (Ö2)

"Bu filmdeki temel etik sorun, insanların yaşama ve uygun tedaviye erişim hakkının ilaç şirketlerinin para kazanma hırsı yüzünden hiçe sayılmasıdır." (Ö6)

Öğrencilerin tamamı dersin son haftasında yapılan tartışmada, filmde geçen ilaç araştırmaları ile ilgili etik sorunları fark etmişlerdir. Öğrenciler durumu şu şekilde ifade etmiştir:

"Filmde geçen etik sorunlardan biri AIDS için AZT'nin fayda sağlamadığı, hatta zarara neden olan deneyler devam ederken fark edilmesine rağmen kullanımına devam edilmesi, klinik ilaç denemelerinde ilaç sektörünün maddi kazanım ve kayıplarının, hasta sağlığının ve yaşamının üstünde tutulmasıdır." (Ö9)

"AZT ilacı AIDS için hayvanlarda denenmeden önce insanlarda denenmeye başlanmış. AZT ilacı sadece kanser tedavisi çalışmaları için hayvanlar üzerinde denenmiş ve $T$ hücrelerini artırdığından AIDS için de kullanılabilir denilerek doğrudan insanlar üzerinde kullanılmıştır. Gerekli kanıtlar olmadan ilacın hastalar üzerinde denenmesi etik bir sorundur." (Ö15)

Film üzerinde son hafta yapılan tartışmalar sırasında öğrenciler, hayvan hakları ihlali ve mahremiyet konularının da filmde yer alan etik sorunlar arasında yer aldığını bildirmişlerdir:

"Rodeo, hayvan hakları aktivistlerinin yıllardır karşı çıktığı bir hayvan hakları ihlalidir. Rodeoya katılan hayvanların seçim yapma şansı yoktur. Bu durum bir hayvan hakkı ihlalidir." (Ö11)

"Ron'un hastanede yattığı odası, hasta mahremiyetini sağlamak için uygun değildir. Hasta ile hekimin arasında geçen konuşmalar yan taraftaki hastalar tarafından rahatlıkla duyulabiliyor." (Ö3)

Film üzerinden son hafta yapılan tartışmada, öğrenciler plasebo uygulamasının etik bir sorun olduğunu belirtmişlerdir:

"Filmde geçen etik ikilemlerden birisi plasebo kullanımıdır. Çalışmaya katılanlar gerçek ilacı alıp almadıklarını bilmemekte, ölmekte olan insanlar zamanlarını işe yaramayan bir ilaçtan medet 


\section{umarak boşa geçirmektedirler. Helsinki Bildirgesi'nin de temel sorunu olan plasebo kullanımına} filmde dikkat çekilmiştir." (Ö11)

Dersin son haftasında yapılan tartışma oturumunda öğrenciler, film tartışmalarının biyoetik sorunları daha iyi fark etmelerine katkı sağladığını, filmin etik eğitiminde kullanılmasının yararlı ve etkili bulduklarını ifade etmişlerdir. Öğrenciler film tartışmalarına daha fazla yer verilmesi gerektiğini, bu nedenle öğretim programının yeniden gözden geçirilmesi gerektiğini vurgulamışlardır.

\section{Tartışma}

Sağlık alanı etik sorunların en yoğun yaşandığı alanlardan biri olarak etiğe ilişkin pek çok soru ve sorunu da barındırmaktadır. Mesleğe ilişkin bilgi, beceri ve değerlerin kazanılması uzun ve biçimlendirici bir eğitim sonucunda gerçekleşmektedir. Sağlık profesyonelinin değer sistemi ve etik sorunlar karşısındaki davranışının temelinde kişilik özellikleri, kurum politikaları ve yasaların yanı sıra özellikle etik eğitimi alıp almaması da belirleyici olmaktadır.

Etik eğitiminin amacı, etik sorunlara farkındalık kazandırılması, bilimin insan için amaç değil araç olduğunun bilinmesi, tedavi ve araştırma süreçlerinde bireylere temel etik ilkeler doğrultusunda yaklaşııması ve bu davranışların içselleştirilmesidir. Bu amaçla da çeşitli öğretim yöntemleri kullanılmaktadır.

Sağın ve Tekgül'ün (2012) biyoetik eğitiminde film kullanımının önemini ortaya koydukları çalışmada, film gösterimi sonunda öğrencilerden alınan geri bildirimlerde filmin "etik farkındalık" artışını sağladığını ifade etmişlerdir. ${ }^{14}$ Self ve arkadaşları (1993), birinci sınıf öğrencilerine etik farkındalık geliştirmek amacıyla film seyrettirme ve tartışma yöntemini kullanmışlar ve bu yöntemin öğrenciler üzerindeki etkisinin olumlu olduğunu belirtmişlerdir. ${ }^{15}$ Rates ve arkadaşlarının (2014) çalışmasında ise öğretim yöntemi olarak filmlerin kullanılmasının öğretim sürecine katkı sağladığı belirtilmiştir. ${ }^{16}$ Yine aynı çalışmada filmler üzerinden tartışmaların uyarıcı olduğu ve öğrencilerin mesleki uygulamada karşılaşabileceği etik sorunlar üzerinde düşünmesine olanak sağlayacağı vurgulanmıştır.

McAllister ve arkadaşlarının (2016) çalışmasında, etik eğitiminde farklı filmlerin kullanımının, öğrencilerin bilişsel, duyuşsal ve etik farkındalıklarının gelişimini destekleyeceği bildirilmiştir. ${ }^{12}$ AleksandrovaYankulovska'nın (2016) çoğunluğu hemşirelik ve ebelik bölümlerinde öğrenim gören 92 öğrenci ile yaptığı çalışmada, öğrenciler filmleri etik sorunları daha iyi anlamalarını sağlayan bir öğretim yöntemi olarak değerlendirmiştir. ${ }^{10}$ Searight ve Allmayer'ın (2014) tıp fakültesi öğrencileri ile yaptıkları çalışmada, öğrenciler etik teorilerin anlaşılmasında filmlerin yararlı olduğunu, alternatif farklı filmlerin de eğitimde kullanılması gerektiğini bildirmişlerdir. ${ }^{17}$ Searight ve arkadaşlarının (2020) "Tıp Etiği ve Filmler" dersi kapsamında yaptıkları ve filmlerle ilgili öğrencilerin günlüklerini analiz ettikleri çalışmalarında, dersin öğrencilerin öğrenmelerini kolaylaştırdığı, eleştirel düşünme becerilerini geliştirdiği saptanmıştır. ${ }^{18}$ Alanyazından elde edilen çalışma sonuçları, bu çalışmanın bulguları ile paraleldir.

Bu çalışmada ele alınan ve gerçek bir hayat hikâyesinden yola çıkarak kurgulanan Dallas Buyer Club filmi, günümüzde içinde bulunduğumuz karmaşık sağlık sisteminin pekçok etik sorunu barındırdığını ortaya koymaktadır. Mevcut sağıık sisteminin karmaşık yapısı içerisinde küresel ve etik sorunların farkında olan ve çözüm üretebilen sağlık profesyonellerine ihtiyaç vardır.

Filmde yer alan ve öğrenciler tarafından da belirlenen temel etik sorunlardan biri, insanlar üzerinde yapılan ilaç araştırmaları ile ilgilidir. İnsan gönüllüler üzerinde yapılan tıbbi araştırmalarda etik ilkeler çerçevesinde plasebo uygulaması konusunda Helsinki Bildirgesi'nin 29. maddesinde dikkat çekilmiştir. ${ }^{19}$ Bu konuda öngörülen düzenleme, klinik araştırmalarda yeni tedavinin plasebo ile değil, "mevcut en iyi" tedavi ile karşılaştıııması, plasebonun sadece kanıtlanmış herhangi bir tedavi bulunmadığında kullanılması yönündedir.

Helsinki Bildirgesi'nin 17. maddesinde, "Insanlar üzerindeki her tıbbi araştırma öncesinde, araştırmaya katılan birey ve grupların veya araştırma konusu olan hastalıktan etkilenen diğer birey veya grupların, araştırmadan görecekleri yarara kıyasla araştırmanın doğurabileceği tahmini tehlike ve sakıncalar da dikkatli bir biçimde değerlendirilmelidir." ${ }^{19}$ ifadesi ile filmdeki uygulamalar karşılaştırıldığında uluslararası bildirge ve kurallara uyulmadığı, bunun toplum ve insanlar üzerinde güvensizlik yarattığı görülmektedir. Oysa 
bildirgenin temel amacı bilim ile insan arasında derinleşen kopukluğu azaltmak, etik değerler açısından insanı, gönüllüyü koruyarak güvence altında olduğunu belgelemektir.

Helsinki Bildirgesi'nin 22. Maddesindeki "Gönüllüler üzerinde yapılacak bütün araştırmaların tasarım ve uygulaması, araştırma protokolünde açık bir şekilde, gerekçesiyle birlikte tanımlanmalıdır. Protokol; finansmanı, destekleyiciyi/destekleyicileri, kurumsal bağları, diğer olası çıkar çatışmalarını, gönüllülere sunulan teşvikleri ve araştırmaya katılmaları sonucu zarar görebilecek gönüllülerin tedavi edilmesi ve/veya tazmin edilmesine ilişkin hükümleri içermelidir." ${ }^{19}$ ifadesi, filmdeki ilaç endüstrisi-hekim ilişkilerinin etik sorunları barındırdığını açıkça göstermektedir.

Öğrenciler tarafından belirlenen bir başka etik sorun cinsiyet ayrımcılı̆ı̆ır. Tüm dünyada tıpta cinsiyet ayrımcılığı olduğu bilinmektedir. Halkın hekimlik gibi prestijli bir alanda kadın hekimleri kabul edememesi pek çok kültürde yaşanan bir sorundur. ${ }^{20}$

Filmde vurgulanan bir başka etik sorun, iktidarların insan bedeni üzerindeki tahakkümüdür. Burada "Biyoiktidar" kavramını açıklamak yerinde olacaktır. Fransız filozof Michel Foucault tarafından ortaya atılmış olan bu kavram, ulus devletlerin amaçlarını "bedenlerin zapt edilmesini ve nüfusun kontrol edilmesini başarmak için sayısız ve farklı tekniklerin uygulanışındaki bir patlama" aracılığıyla, özellikle de istatistik ve olasılığın kullanılması yoluyla, düzenleme pratiği olarak tanımlar. Foucault’ya göre biyoiktidar modern ulus devletin ve modern kapitalizmin ortaya çııışında önemlidir. ${ }^{21}$ Terim tam anlamıyla "bedenler üzerine kurulan iktidar ve iktidar ilişkileri"nden bahseder. Bu filmde hangi tedavilerin alınabileceğine, hangilerinin alınamayacağına FDA, dolayısıyla iktidar sahipleri karar vermektedir. Kendi gösterdikleri yöntemin başarılı gibi gözükmesi, kısmi başarı gösteren diğer yöntemlerin ise ortadan kaldırılması gibi kamuoyunu yanıltıcı davranışlar sergilenmektedir.

Bilim, insanın sağlık sorunları için çözüm arayışındaki bir etkinlik olarak var olurken, film bilim ile toplum arasındaki kopukluğu gözler önüne sermektedir. Topluma hizmet sunan sağlık profesyonellerinin etik sorunları fark edip çözüm önerisi araması, oluşan bu kopukluğun giderilmesine katkı sağlayacaktır. Etik eğitiminde, öğrencilerin etik farkındalık kazanmasında ve farklı çözümlerin sonuçlarını değerlendirmesinde ilgili filmleri izlenmesi etkili olacaktır.

\section{Sonuç}

Çalışmanın sonuçları Dallas Buyers Club filmi özelinde elde edilmiştir. Sonuç olarak etik eğitiminde kullanılan film analizinin, öğrencilerin etik sorunlarla ilgili farkındalıklarının artması üzerinde olumlu etkisi olduğu görülmüştür. Bu çalışma kapsamında yer verilen Dallas Buyers Club filmi özellikle araştırma etiği, ilaç-hekim ilişkilerinde ortaya çıkan etik sorunlar, ayrımclık, hasta özerkliği, aydınlatılmış onam, ötekileştirme gibi temel etik konularının farkına varılmasında öğrenciye yol gösterici niteliktedir.

Etik sorunların farkına varmak, çözüm önerileri sunmanın temel ilkesidir. Sağlık profesyonellerinin etik eğitiminde filmlerin kullanılması, etik sorunların farkına varmalarını, bu konuda derinleşebilmelerini, çözüm önerilerileri konusunda yaratıcı olmalarını, önyargılarını sorgulamalarını ve sağlık sistemini etik açıdan değerlendirebilmeyi kolaylaştırmaktadır. Kuşkusuz filmlerin doğru seçimi ve derslerdeki kullanımı eğiticinin sorumluluğundadır.

\section{Bilgi}

Yazarlar arasında çıkar çatışması bulunmamaktadır.

\section{Etik onay}

Çukurova Üniversitesi Tıp Fakültesi Girişimsel Olmayan Klinik Araştırmalar Etik Kurulu (50243401/2020-18)

\section{Kaynaklar}

1. Sönmez V. Türkiye'de Eğitimin Kalitesi ve Geleceği. Hacettepe Üniversitesi Eğitim Fakültesi Yayını 1986;1(1):49-63.

2. Tezcan M. Türk Kişiliği ve Kültür-Kişiliği ilişkileri. Ankara: Kültür Bakanlığı Yayını;1997.

3. Örnek Büken N, Demir M, Akpınar A. Hacettepe Üniversitesi Tıp Fakültesi Asistan Etik Eğitimi. In:Sağlık Bilimlerinde Etik Eğitimi Sempozyum Kitabı. Ankara:Ankara Üniversitesi Basımevi; 2015. 
4. Gül Ş, Genç Kuzuca I, Yalım NY. Hemşirelerin etik eğitiminin meslek hayatına yansıması konusundaki görüşleri. Türkiye Biyoetik Dergisi 2016;3: 85-97.

5. Karabulut SD, Yıldırım RV. Tıp Etiği Eğitiminde Video/Film Gösterimi ve "Monday Mornings" Dizi Önerisi Usage of Video/Films in the Medical Ethics Education and "Monday Mornings" Series Suggestion. Türkiye Biyoetik Dergisi 2018;5(1):3-8.

6. Lumlertgul $\mathrm{N}$ et al. Cinemeducation: a pilot student project using movies to help students learn medical professionalism. Medical Teacher 2009;31:327-332.

7. Arroio A. Context Based Learning: A Role for Cinema in Science Education. Science Education International, 2010;21(3):131-143.

8. Blasco PG, Moreto G, Pessini L. Using movie clips to promote reflective practice: a creative approach for teaching ethics. Asian Bioethics Review 2018;10:75-85. Erişim: https://doi.org/10.1007/s41649-018-0046-z

9. Oh J, Kang J, De Gagne JC. Learning concepts of cinenurducation: An integrative review. Nurse Education Today 2012;32(8):914-919.

10. Aleksandrova-Yankulovska S. An innovative approach to teaching bioethics in management of healthcare. Nursing Ethics 2016;23:167-175.

11. Oh JA, Im MH. Analysis of research papers using movies in nursing education. The Journal of Korean Academic Society of Nursing Education 2011;17(3):395-404.

12. McAllister $M$ et al. The viewing room: A lens for developing ethical comportment. Nurse Education in Practice 2016;16(1):119-124.

13. Katz et al. Comparative use of Tuskegee Syphilis Study Film vs. Text Triggers to Teach Bioethics: The Spheres of Ethics Teaching Using Film (SOETUF) College Study. Divers Equal Health Care 2018;15:199-205.

14. Sağın FG, Tekgül H. Tıp eğitiminde sinema kullanımı: temel ve klinik bilimler integrasyonu, biyoetik eğitimi ve daha ötesi... Biyoetik Araştırmaları. Ed: Ülman YI, Genç SV. Türkiye Biyoetik Derneği Yayını: İstanbul;2012. p:265-268.

15. Self DJ, Baldwin DC Jr, Olivarez M. Teaching medical ethics to first-year students by using film discussion to develop their moral reasoning. Academic Medicine 1993;68(5):383-385.

16. Rates CMP et al. The use of films as a teaching tool for the teaching-learning process in bioethics. Invest Educ Enferm 2014;32(3):421-429.

17. Searight HR, Allmayer $\mathrm{S}$. The use of feature film to teach medical ethics: overview and assessment. International Journal of Modern Education Forum (IJMEF) 2014;3(1): 1-6.

18. Searight HR et al. The use of feature film for teaching undergraduate bioethics: Course format and assessment through student narratives. InSight: A Journal of Scholarly Teaching 2020;15:33-51.

19. Dünya Tıp Birliği Helsinki Bildirgesi, http://www.journalagent.com/aot/Helsinki_Decleration_tur.pdf

20. Genç Kuzuca i. Türkiye' De Tıpta Uzmanlık ve Akademisyenlik Aşamalarında Cinsiyetçi Yaklaşımlar. Kadın Çalışmaları ABD Yüksek lisans Tezi. Ankara Üniversitesi Sosyal Bilimler Enstitüsü 2007.

21. Bilişli Y, Çakmak F. Michel foucault'nun biyo-iktidar perspektifinden türkiye'de gazete sağlik haberlerinin analizi. Pamukkale Üniversitesi Sosyal Bilimler Enstitüsü Dergisi 2019;(35):323-339. 